\title{
Uncovering the role of IFNAR1 in experimental cerebral malaria
}

\author{
Elizabeth Ball', Carlos Penha Gonçalves \\ From Parasite to Prevention: Advances in the understanding of malaria \\ Edinburgh, UK. 20-22 October 2010
}

Cerebral malaria $(\mathrm{CM})$ is a severe complicated form of malaria, resulting in an overwhelming inflammatory response in the brain due to infection from Plasmodium-falciparum[1]. Only a fraction of malaria infected individuals develop CM and it has been shown that both genetic and non-genetic factors determine CM susceptibility [2]. Variants in Interferon alpha receptor-1 (IFNAR1) have been associated with protection from $\mathrm{CM}$ in humans [3] and in susceptibility to severe forms of malaria, such as CM. As in humans, susceptibility of mice to $\mathrm{CM}$ is determined by genetic factors (unpublished data, Sambo et al).

Type-I Interferon, $\alpha / \beta$ (IFN-I), plays a key role in regulating the immune response through release of proand anti-inflammatory cytokines and stimulating antigen presentation and cellular cytotoxicity. Its expression has been found to be up regulated upon infection with viruses and bacteria, and can illicit protective or diseaseaggravating effects [4]. From this knowledge we hypothesize that IFNAR1 is a determinant of the inflammatory response that leads to development of Experimental cerebral malaria (ECM).

Ifnar1-/- mice were infected with Plasmodium berghei ANKA (P.berghei ANKA) and assessed for survival and development of ECM. 70\% of mice did not develop ECM and died 28-30 days later from anemia and hyper-parasitemia. Ifnar1-/- mice do not show a decrease in parasite burden, and display mild blood brain barrier breakage. We are currently investigating brain vasculature and infiltration of inflammatory molecules within these mice and are conducting transfer experiments using Ifnar1-/and Rag2-/-mice with the aim of defining the role of IFNAR1 in development of ECM upon infection with

Disease Genetics Group, Instituto Gulbenkian de Ciência, Oeiras, Portugal
P.berghei ANKA, and determining where and how this protection is inflicted.

Published: 20 October 2010

\section{References}

1. Idro R, Jenkins NE, Newton CRJC: Pathogenesis, clinical features, and neurological outcome of cerebral malaria. Lancet Neurology 2005, 4:827-40.

2. Bagot S, Campino S, Penha-Goncalves C, Pied S, Cazenave PA, Holmberg D: Identification of two cerebral malaria resistance loci using an inbred wild-derived mouse strain. PNAS 2002, 15:9919-9923.

3. Aucan C, Walley AJ, Hennig BJW, Fitness J, Frodsham A, Zhang L, Kwiatkowski D, Hill AVS: Interferon-alpha receptor-1 (IFNAR1) variants are associated with protection against cerebral malaria in The Gambia. Genes and Immunity 2003, 4:275-282.

4. Decker T, Muller M, Stockinger S: The yin and yang of type I interferon activity in bacterial infection. Nat. Rev. Immunol 2005, 5:675-687.

doi:10.1186/1475-2875-9-S2-P3

Cite this article as: Ball and Gonçalves: Uncovering the role of IFNAR1 in experimental cerebral malaria. Malaria Journal 2010 9(Suppl 2):P3.

\section{Submit your next manuscript to BioMed Central and take full advantage of: \\ - Convenient online submission \\ - Thorough peer review \\ - No space constraints or color figure charges \\ - Immediate publication on acceptance \\ - Inclusion in PubMed, CAS, Scopus and Google Scholar \\ - Research which is freely available for redistribution \\ Submit your manuscript at www.biomedcentral.com/submit}

(c) 2010 Ball and Gonçalves; licensee BioMed Central Ltd. This is an open access article distributed under the terms of the Creative Commons Attribution License (http://creativecommons.org/licenses/by/2.0), which permits unrestricted use, distribution, and reproduction in any medium, provided the original work is properly cited. 